THE INDO-BULGARIAN FRIENDSHIP ASSOCIATIONS

\title{
AS A TOOL OF BULGARIA'S POLITICS IN INDIA (50S - 80S OF THE 20TH CENTURY)
}

\author{
Violina Atanasova, Assist. Prof. PhD
}

v_st_a@abv.bg

Institute for Historical Research - Bulgarian Academy of Sciences

Sofia, Bulgaria

Abstract: The paper analyses the activity of the IndoBulgarian friendship associations in India. They are one of the main tools for promoting Bulgaria in this country. Along with this, their development during the years is a testimony to the changes in the interests and political line of the Bulgarian government in regards to the Bulgarian-Indian relationships.

Keywords: Indo-Bulgarian Friendship Associations, Cultural Policy, India, Bulgaria

\section{ИНАО-БЪАГАРСКИТЕ АРУЖЕСТВА ЗА ПРИЯТЕАСТВО КАТО ИНСТРУМЕНТ НА ПОАИТИКАТА НА БЪАГАРИЯ В ИНАИЯ}

\author{
(50-80 гоАИнИ на 20 век) \\ Виолина Атанасова, Аоц. А-р
}

Институт за исторически изслеАвания при БАН

Софияя, България

Резюме: В статията се разгежАа Аейността на инАОбългарските Аружества за приятелство в Индия. Те са еАин от основните инструменти за популяризиране на България в тази страна. НареА с това тяхното развитие през годините служи като свидетелство за промяната на интересите и политическата ^иния на българското правителство в българоинАй̆ските Отношения.

КАючови Ауми: ИнАо-български Аружества, културна пОлитика, ИнАия, България

В изследването се разглежАа вьпросът за инАо-българските Аружества за приятелство, които преАставляват основен инструмент за 
провежланата в течение на 30 голини културна политика на България в ИнАия.

Той може $\Delta$ а се постави в контекста на нашумя^ата в послеАно време в бьлгарската историография тема за "меката сила" в межлународните отношения (Koev, 2015), (Samuilova, 2017), (Vasilenko, 2016) и мр. Разбира се работата с неправителствени организации е само еАна от нейните проекции, но тя представляваотражение на общите насоки на българската политика в Индия като цяло. Темата има и Аруг, макар и слабо засегнат, аспект - за възможностите за разпространение на чуждото културно наследство в отлалечени страни със среАствата на Авустранните връзки.

Поставям си за цел Аа отговоря на Ава важни въпроса: пьрво, за развитието на българо-индийските отношения през 30-голишния периол на българо-инАийските отношения и за мястото на инАо-българските Аружества за приятелство в тях и второ, за еорективността от тази Аейност през различните периоли като свилетелство за промяната на интересите И политическата ^иния на българската страна по отношение на ИнАия.

За целите на изследванетоса използвани главно материали от архива на МВнР, благоларение на които може $\Delta а$ се прослели напредька в Аейността на дружествата през различните етапи на Авустранното сътруаничество между ИнАия И България, както и привнасянето на нови орорми и средства за неговото обогатяване.

\section{$* * *$}

Още през 1956 г. по инициатива на българската ^егация в Аелхи започва създаването на индо-български културни Аружества за приятелство. Министерството на външните работи на НР България я олобрява като изтьква: „Инициативата за основаване на инАо-български комитети за приятелство е похвална. Тези комитети ще Аопринесат за популяризирането на Наролна република България всреА по-широки крьгове на инАийската общественост. С тяхна помощ и от тяхно име Аегацията ще може по-лесно и по-нашироко $А$ извършва своята културна и пропагандна Аейност в ИнАия"'.

1 щАА, dp. 1477. оп.13, a.e. 305, ^. 122. / [CDA, f. 1477. op.13, a.e. 305, L. 122.] 
Работата с Аружествата зависи от релица обстоятелства, които засягат както Авустранните отношения межАу България и ИнАия, така и приоритетите в българскатавъншна политика.

Ао началото на 70-те голини, макар и относително Аобри, българо-инАийските отношения не се отличават с особена Аинамика и активна Аейност в каквато и Аа било сорера. Има трудности в областта на икономическите отношения, политическите връзки са относително стабилни, но се развиват вяло, а културните споразумения и Културната спогодба от 1963 г. не се изпьлняват. Това показва, че не може $а$ с се говори за кой-знае какъв интерес към Авустранно сътрудничество от страна и на Авете Аьржави.

За пояснение искам Аа добавя, че слеА Втората световна война страните от третия свят представляват нов фоктор в межАународните отношения, към привличането на които имат интерес силите от Авете страни на „желязната завеса". Но те преминават през различни вътрешно- и външнополитически колизии, които независимо от стратегическите цели на СССР и на сателитните му Аьржави като цяло,труАно могат Аа бъАат оценени еАнозначно И поражАат сьмнения в изначалните планове $а$ бъдат привлечени като съюзници в борбата межАу Авете системи².

Нарел с това трябва $л а$ се отбележи, че културната политика на българската Аьржава в чужбина пьрвоначално е ориентирана главно към социалистическия лагер и към страни, в които има сравнително многобройна и устойчива българска Аиаспора.

Най-накрая трябва $\Delta а$ се изтькне и обстоятелството, че българското правителство не Аооценява силата на културната политика като цяло 3 . За тази сорера не се отлелят Аостатьчно среАства, за което в конкретния пример с Индия можем да сьАим по голямото количество

2 Като пример за това в самата Индия могат да се посочат Аясната политика на ^а^ БахаАур Шастри и антикомунистическите настроения в страната в средата на 60-те години (AMBнР, оп. 21, преп. 1190, ^. 1. / [AMVR, op. 21, Rev. 1190, I. 1]), както и инАОКитайските сбльсъци от този периоА (АМВМР, оп. 20а, преп. 849, ^. 1. / [AMVmR, op. 20a, article 849, letter 1]).

3 През 50-теи 60-те години преобладава идеологическият "пьлнеж“ на понятието "ку^тура". 
от^ожени или неприети от бъ^гарската страна инициативи, като изложби, концерти и пр. ${ }^{4}$.

Що се отнася $А$ самите инАо-български Аружества за приятелство, тук целта е $\Delta а$ се пропагандира среА индийските гражАани енна впечатляваща картина на социалистическия начин на живот, както проличава от Аокументите за залачите на пропагандната работа в Индия, които вкАючват: отразяване на миролюбивите външнополитически стьпки на нашето правителство; икономическите, социални и културни приАобивки слеА 9-ти септември 1944 г.; стопанските Аостижения на България; помощта, която България оказва на новоосвободените народи във всяка област; борбата на нарола ни срещу расовата и национа^ната Аискриминация 5 . От Аруга страна обаче, както се посочва в напьтствие на МВнР Ао $е$ егацията, „като се има предвиА, че комитетите са организации на местни гражАани, в бьлещата работа с тях Аегацията $\Delta \mathrm{a}$ се пази $\Delta \mathrm{a} \Delta \mathrm{a} \Delta \mathrm{e}$ основание за обвинения за вмешателство в работата им. Насоките и влиянието, което следва да се оказва върху тяхната

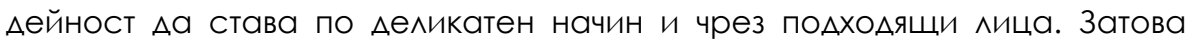
конкретни указания не могат $\Delta$ a ce $\Delta$ алат, а легацията следва $\Delta а$ изработи поАхоА"6.

Между ангажираните с този въпрос организации - Комитета за приятелство и културни връзки с чужбина (КПКВЧ), Министерството на външните работи (МВнР) и Аегацията (от 1961 г. Посолството на НР България в $А е \wedge х и)^{7}$ не винаги съществува еАинно гледище по въпросите за работата не само с Аружествата за приятелство в ИнАия, но и за културното сътрудничество с тази страна като цяло. КПКВЧ преАлага мащабни програми - преАвижАат се изАаване по линията на Аружествата на бюлетини, посветени на индийско-българската Аружба; организиране на кръжок за изучаване на български език като секция към инАо-българското Аружество в Аелхи; организиране на бесели за

\footnotetext{
${ }_{4}^{4} \mathrm{AMBнP}$, оп. 21, А. 98, преп. 1190, ^. 1 и Ар. / [AMVR, op. 21, d. 98, Rev. 1190, I. 1, etc.]

${ }^{5}$ AMBнP, оп. 20a, А. 52, преп. 849, ^. 4. / [AMVR, op. 20a, d. 52, article 849, I. 4.]

6 ЦАА, dp.1477. оп. 13, a.e. 305, ^. 122. / [CDA, f.1477. Op. 13, a.e. 305, І. 122.]

7В работата с Аружествата участват и Аруги организации - министерства и организации (АКМС, Комитетьт на българските жени и пр.), но те нямат самостоятелно място при взимането на решения по въпросите на Авустранното културно сътруАничество.
} 
България по минията на Аружествата, съпроводени с музикални илюстрации, прожекции на фрилми и Ар.8. Тези инициативи обаче не винаги са съобразени както с предпазливия поАхоА на МВнР и С вьзможностите на бьлгарската Аьржава $а$ ги подкрепя, така и сьс ситуацията в ИнАия и с организационните особености на самите инАОбългарски Аружества,в резултат на което голяма част от мероприятията остават нереализирани.От своя страна служителите в Посолството, които използвайки мичните си служебни пьтувания извьн Аелхи иса в по-голяма степен запознати с местните условия, се стремят Аа установят възможно най-широки контакти с инАийски гражАани от размични политически партии и обществени организации и $а$ а упражняват контрол вьрху останалите български институциии организации, ангажирани с този вьпрос.

Кьм края на 50-те години са съзАадени осем Аружества в Аелхи и в Аруги големи центрове на Индия - в Колката9, Канпур, Мумбай10,

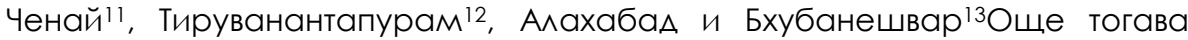
българската страна планира те $а$ б бълат централизирани в еАна голяма фелерация, която би могла $а$ а лобира за бьлгарските интереси в тази страна, както и $а$ а се постави тяхната Аейност на планова основа. Като пример се посочват еАинното инАО-съветско Аружество с 42 кАона в цяла ИнАия и особено инАО-КИтайското АрУжество за приятелство с 18 щатски и областни к^она и 140 низови организации, Аейността на което С полписване на петиция за приемане на КНР в ООН налхвьрля рамките на еАна организация за културно-просветна Аейност и се характеризира и с политически изяви ${ }^{14}$. За полобряване на работата с Аружествата МВнР съветва българските Аип^оматически преАставители в Аелхи Аа използват и опита на колегите си в големите капиталистически страни ${ }^{15}$. Показател за големите очаквания, които се възлагат на Аружествата от българска

${ }^{8} Ц \triangle \mathrm{A}$, dp. 1477, оп. 16, a.e.350, ^.28. / [CDA, f. 1477, Op. 16, a.e.350, I.28.]

9В архивните Аокументи тук и по-нататьк са използвани старите названия на граАовете: Калкута

${ }^{10}$ Бомбай

${ }^{11}$ MaАpac

12ТриванАрум

13Буванешвар

$14 \longleftrightarrow \Delta \mathrm{A}$, фp. 1447 , оп. 16 , a.e. 350 , ^. 53-58. / [CDA, f. 1447, Op. 16, a.e. 350, I. 53-58.]

15 Пак там, ^. 53 / [CDA, f. 1447, Op. 16, a.e. 350, I. 53.] 
страна (най-вече с възможностите $а$ с се популяризира нашата страна чрез книги и статии по въпросите на българското социалистическо развитие), е големият брой на посетилите Бьлгария инАийски гражланипрез пьрвия периол на българо-индийските врьзки. Тяхното пребиваване в нашата страна като прави^о протича на високо равнище. Така, пьрвото посещение на делегация на инло-българското Аружество за приятелство в ИнАия преминава със съАействието на реАица отговорни ^ица - неговият член Гуршаран Сингх, който проявява интерес към селското стопанство на НР България се среща с министьра и зам. министри на земеделието и горите, с тогавашния научен секретар на БАН, с ректора на Висшия селскостопански институт, с ръковоАни Аейци на ЦКС и пр., посещава Окръжната селскостопанска изложба в П^овАив, няколко научно-изследователски селскостопански институти, язовири, електроцентрали, заво и $^{16}$.

В насоките, които Министерството Аава на българската легация в Аелхи, се препоръчва в дружествата $\Delta а$ се привличат „авторитетни и влиятеАни Аица"17, или с Аруги Ауми Аица, които заемат важни постове и А^ъжности в политически и културни организации, Аьржавни и правителствени учрежления. В същото време не трябва $а$ а налценява значението на дружествата за провежланата по това време българска политика по отношение на Индия. Аегацията не приема прел^ожението

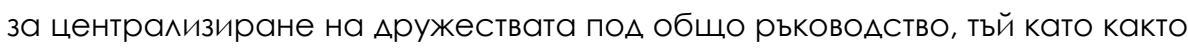
се посочва в енна преписка с Министерството на външните работи, въпросьт е Аеликатен - те не са организирани по почина на $\triangle$ елхи, а са инициатива на самата легация и се разчита на ^ични приятелства и познанства на нейните членове в различните градове на ИнАия ${ }^{18}$.

Сьобщава се също, че така наречените „инАо-български Аружества за приятелство" всъщност не са такива в собствения смисъл на тази дума - в различни сведения за тяхната организация могат $\Delta а$ бълат направени изволи за ограничения характер на тяхната Аейност: "....Както се вижАа от справките и няколкократните обяснения на посолството, в случая става дума по-скоро за комитети, а не за

\footnotetext{
${ }^{16} \mathrm{AMBHP}$, оп. 15, п.н. 353, ^. 3. / [AMVR, op. 15, p.n. 353, I. 3.]

${ }^{17} \mathrm{AMBнP}$, оп. 13, п.н. 305, ^. 122. / [AMVR, op. 13, p.n. 305, I. 122.]

${ }^{18} \mathrm{AMBнP}$, оп. 14, п.н. 264, ^. 61. / [AMVR, оp. 14, p.n. 264, I. 61.]
} 
дружества в този смисъл, в който ние го разбираме в България. В някои случаи, въпреки че се смята за дружество и се водят на отчет известен брой членове фрактически има само еАин или Авама Ауши, които организират мероприятия сьс сълействието и финнансовата помощ на посолството... От приложения списък се вижАа, че числото на членовете на ръковолствата е различно по брой и разпределение на функциите. В много случаи са вкАючени почетни патрони, съветници и пр. за повАигане само авторитета на дружеството и осигуряване по-голям успех на мероприятията. Тази практика е широко разпространена в различните ИнАИйски организации. В АействитеАност работата се върши гАавно от еАин-Авама членове на рьководството, които обикновено са секретарите, а само в някои случаи предселателите... Няма валилна за всички Аружества орорма на организация - въпросът се решава спореА

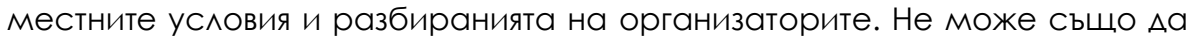
се говори за плановост в тяхната Аейност"19.

През цялото време продьлжава $а$ а стои въпросьт $3 а$ фоинансирането на дружествата: пребиваването на индийските гости в България зависи изцяло от българската страна - пьлна изАръжка и пьтни 20; същото се отнася и Ао организирането на разнообразните мероприятия пол егидата на Аружествата в различни инАийски градове и материалната база²1; поставен е и вьпросьт за заплащане на прелселателите и секретаритена дружествата и т.н.Мероприятията, провежлани от тях - чествания на важни за българската Аьржава годишнини, прожектиране на оилми, Аекции и пр., също не са масово посещавани от инАийските гражАани - цифррите на тази посещаемост варират межАу няколкостотин и няколко (Аве-три) хиляАи Ауши 22 .

Шестлесетте голини не бележат съществен прогрес в развитието на дружествата: нещо повече на този етап като че $и$ интересьт на българската страна към контакти с ИнАия спала и това вероятно се Аьлжи както на антикомунистическите настроения в авторитетни крьгове на инАийското общество слеА смьртта на Неру през 1964 г. и на

\footnotetext{
19 AMBнР, оп. 21, преп. 1200, ^.10-11. / [AMVR, op. 21, Rev. 1200, I.10-11.]

${ }^{20} \mathrm{AMBнP}$, оп. 17; преп. 478, ^. 1. / [AMVR, op. 17; Rev. 478, I. 1.]

${ }^{21} \mathrm{AMBнP}$, оп. 18, преп. 663, ^. 12. / [AMVR, op. 18, article 663, letter 12.]

22ЦАА, q. 1477, оп. 18, a.e. 663, ^. 12. / [CDA, f. 1477, Op. 18, a.e. 663, I. 12.]
} 
КИтайско-инАИйските коноАикти от 1962 и 1967 г., така и на някои проблеми в икономическите отношения с тази страна.

В отчетния АоклаА на легацията за 1964 г. се отбелязва: „Значителен културен обмен през 64 г. посолството разви по неофициилен пьт: чрез инАо-българските Аружества за приятелство и чрез редица инАийски културни клубове и организации. На полобна Аейност инАй̆ското правителство не пречи и затова размерьт на тази наша културна Аейност зависи само от нашата активност и материални възможности. Този фокт говори, че в ИнАия, независимо от това, че в послеАно време правителството води курс на завой налясно, все още съществуват своболи"23. Тази оценка обаче трябва да се разглежла на фона на офрициалното културно сътрудничество, което в този периол елва ^и би могло Аа се нарече заловолително. (Така например Планьт за културно сътрудничество от 1964 г. остава неполписан) ${ }^{24}$.

По същото време възниква идеята за създаване на културни центрове в А^жир и ИнАия, която остава неосьществена. Тогава Българското посолство в Аелхи предприема мерки за укрепването на Аружествата за приятелство в организационен и материален п^ан. Счита се, че работата на дружествата е уловлетворителна и би било по-лобре $\Delta$ а се разчита на тях, отколкото $а$ а се открива културен центьр, което не би оправлало разхолите 25 .

Решенията обаче се разминават с практиката: сьтрудниците на българското посолство в Аелхи постоянно алармират за неАостиг на среАства за тази цел (Аори за посещения на посланика и сьтрудници на

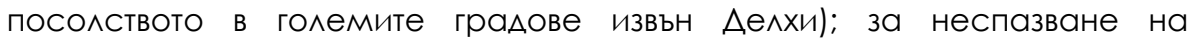
ангажименти от страна на КПКВЧ при организиране на мероприятия $26 ; 3 а$ отказ $\Delta$ а се фонансират Аружествата и за Аруги нередности в работата с тях. Преломен момент за развитието на българо-инАийските отношения като цяло и за работата на Аружествата в частност са Авете визити на правителствените ръководители на Индия и България (през 1967г. на премиер-министьра на Индия Индира Ганди в Бьлгария и ответната

\footnotetext{
${ }^{23} \mathrm{AMBнP}$, оп. 21, преп. 1190, ^. 9. / [AMVR, op. 21, Rev. 1190, I. 9.] ${ }^{24} \mathrm{AMBHP}$, оп. 21, пре. 1190, ^. 7. / [AMVR, op. 21, trans. 1190, I. 7.] ${ }_{25}$ AMBнP, оп. 21, А. 99, преп. 1200, ^. 12-13. / [AMVR, op. 21, d. 99, Rev. 1200, I. 12-13.] 26щАА, ф. 1477, оп. 14, a.e. 277, ^. 73-74; AMBнР, оп. 21, преп. 1195, ^. 39 и Ар. / [CDA, f. 1477, Op. 14, a.e. 277, I. 73-74; AMVR, op. 21, Rev. 1195, I. 39, etc.]
} 
визита на Тодор Живков в Индия през 1969 г.). Топлите отношения, установени межлу Авамата, несъмнено способстват за увеличаване на интереса на широката общественост кьм Аругата страна. Новата политика в областта на културата от началото на 70-те голини, насочена към активно пропагандиране на българската култура в чужбина, за целите на която служат новооткритите културни центрове в различни

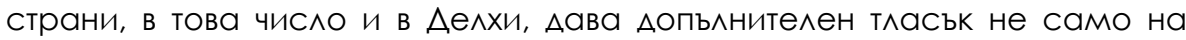
разширяването на врьзките межлу ангажираните с културното сътрудничество организации, но и на увеличаването на Аичните контакти С техни представители от различни социални слоеве. В еАин АокАаА На посланик Стоян Заимов от 1978 г. се отбелязва, че целевата група, към която трябва $\Delta а$ се насочва бьлгарската пропаганла, е образованата инАийска прослойка в Аицето на интелигенцията от различни сорери, най вече от писателски и културни среди, която би могла $А$ възприеме пропагандираните от българска страна илеи 27.

С ^ичното участие на АюАмила Живкова в българо-индийските културни отношения започват $\Delta a$ се преололяват и $\Delta в е$ негативни тенденции, които се наблюдават през всички предишни години. Става Аума пьрво, за недооценката на културния фрактор в Авустранните отношения, и второ, за еАнопосочни прояви на културна активност от българска страна.

Акцент се поставя върху илеологическата пропаганда, чрез която се цели $\Delta а$ се покаже превъзхолството на социалистическата система във всички области. И Аокато в официалните културни контакти инАийската страна налага принципа на реципрочността, т.е. изисква се межлу мероприятията, организирани от Авете страни $\Delta а$ съществува баланс, в работата с Аружествата преобладава стремежьт $\Delta а$ се наложи българското влияние, а не да се осьществява обмен.

В новите условия, когато културната политика на българската Аьржава не само следва нови насоки, подхранвани от илеите за развитие и осъществяване на практика на програмите за естетическото възпитание,запо-зальлбочено осмисляне на националното минало и неговите съвременни проекции, и пр., но и възприема нов подхол към чужАите култури, към възможностите, които те предлагат за целенасочено

${ }^{27} \mathrm{AMBнP}$, оп. 34, преп. 1218, ^. 20. / [AMVR, op. 34, Rev. 1218, I. 20.] 
и планирано обогатяване на българската култура, интересьт към Индия среА български културни кръгове и среА цялото българско общество се засилва. Уважението към нейните културни постижения, което демонстрира $\wedge$. Живкова при посещенията си в тази страна, залягат в основата на българо-инАийските културни отношения от този периоА: на тях им е отАелено специално място във връзка както със съвременните приоритети за духовен растеж на България, така и с нейните стремежи $\Delta$ а открие Аревните си корени.

В този периол нараства и ролята и на инАо-българските Аружества за приятелство. Кьм края на 70-те голини по Аанни на Българското посолство в Аелхи техният брой е около 60 в 16 инАийски щата. Отново се поставя въпросът за обединяването им в еАинна организация и през 1978 г. за прьв пьт в Аелхи се сьбират рьководствата на дружествата от различни щати ${ }^{28}$. Много от илеите на $\wedge$. Живкова намират добър прием среА широки крьгове от инАийската общественост и най-вече инициативите за естетическото възпитание на Аецата. От своя страна тя подАьржа широки контактис инАийски обществени и културни Аейци.

През 1978 г., когато пристига в Колката, Живкова е посрещната и поздравена с културна програма в нейна чест от местното инАобългарско Аружество 29. При посещението си в Индия през 1981 г.нареА със срещите с преАставители на инАийското правителство и ръковоАни Аейци на ИНК тя провежАа разговори и с ръководството на новосъзАалената Асоциация за бьлгаро-индийска Аружба, което несьмнено спомага за активизирането както на тази организация, така и на клоновете й в различните щати ${ }^{30}$.

През 1977-79 г., когато ИНК претьрпява пьрвата си сериозна загуба в изборите, в Аружествата за приятелство настьпва криза, тъй като повечето от техните предселатели са членове на партията ${ }^{31}$. Благодарение на Аичните контакти на Живкова, както и на широките връзки на служителите на Посолството тя е преололяна. Нещо повече,

28Пак там, ^. 19. / [AMVR, op. 34, Rev. 1218, I. 19.]

${ }^{29} \mathrm{AMBнP}$, оп. 35, преп. 1362, ^. 8. / [AMVR, op. 35, Rev. 1362, I. 8.]

${ }^{30} \mathrm{AMBнP}$, оп. 38, преп. 1219, ^. 6. / [AMVR, op. 38, article 1219, letter 6.]

31 AMBнР, оп. 34, преп. 1218, ^. 21. / [AMVR, op. 34, Rev. 1218, I. 21.] 
през тези две години дейността на дружествата се активизира в сравнение с предилущия периол. За успешното развитие на връзките на българското Посолство с инАийската общественост говори и понататьшното развитие на българо-индийските културни врьзки. През 1978 г. без настояване от индийска страна за спазване на принципа на реципрочността в Аелхи е открит Бьлгарският културно-инорормационен център (БКИЦ). СлеА откриването на БКИЦ в Аелхи българската пропаганда в ИнАия се обогатява с нови среАства и фрорми. ЕАна от залачите на Аиректорите на центьра е полАьржането на тесни контакти както с Асоциацията за бьлгаро-инАийска Аружба, която става основен Авигате^ на неговите инициативи, така и с Аружествата в различните ИнАй̆ски щати. За тази Аейност през 80-те гоАини се отпускат и Аостатъчно среАства. Асоциацията, както се отбелязва в еАин $А$ олаА на Евгения Камова, Аиректор на БКИЦ, участва във всички по-значими мероприятия, организирани от центьра ${ }^{32}$ - изложби, прожекции на български филми, конференции и симпозиуми, свързани с честването на важни голишнини, посещения на делегации в двете страни и много Аруги.

Активна е и Аейността на дружествата в щатите, межАу сътруАниците на БКИЦ и техните ръковоАства текат интензивни контакти. Ha този етап те представляват елно отосновните среАства за привличането на обществени Аейци, парламентаристи, политици и учени в организираните от българска страна важни културни и научни мероприятия 33 .От края на 70-те голини се разгръщат широки мероприятия в Индия, свързани с честването на 1300-годишнината от съзАаването на българската Аьржава, които както отбелязва М. Скарлатов, пьрвият Аиректор на БКИЦ в Аелхи, не се свежАат само Ао еАно „протоколно честване на тази бележита $А$ ата, а $\Delta о$ изпьлнението на еАна комплексна програма, имаща стимулирането на нови постижения във всички области на живота"з4.

На този етап Аружествата стават важна част от реализирането й, тъйкатоиндийскатастранаотхвърляпредложениетозасъздаваненаофрициа

\footnotetext{
${ }^{32} \mathrm{AMBнP}$, оп. 43-16, сп. 431, ^. 9. / [AMVR, ор. 43-16, magazine 431, letter 9.]

33 АМВнР, оп.40, преп.1643, ^. 7. / [AMVnR, op. 40, rev. 1643, І. 7.]

34 AMBнP, оп.. 35, преп. 1362, ^. 22-23. / [AMVnR, ор.. 35, article 1362, I. 22-23.]
} 
^наНационалнакомисиянаправителствено равнищезаотбелязванетона 1300-годишнинатаотсьздаването на българската Аьржава, катопояснява, че такива комисии могат $\Delta а$ бъдат изградени по миния на инАобългарските Аружества за приятелство ${ }^{35}$. И през слеАващите голини Аружествата остават еАин от основните разпространители на инициативите на културния център в ИнАия: лекции и сказки, които вкАючват исторически и географоки теми; изложби и филми; чествания и вечери и пр. СреА най-популярните форми на тази дейност саразмяната на фолклорни състави, изпьлнението на които се посреща топ^о и в Авете страни.

В заключение може $а$ а се каже, че от средища за рекламиране на социалистическото развитие и социалистическия начин на живот инАо-българските Аружества се преврьщат в Аействен инструмент за провеждането на българските интереси в Авустранните отношения межАу България и ИнАия като цяло, когато на смяна на илеологическите клишета иАва разпространяването на културни ценности, в това число и на българското културно наследство. Това особено ясно проличава в голините на смяна на инАийските правителства.

Hapes с това те играят значителна роля за разширяването на средите, в които се осъществява културно-пропагандната Аейност на българската страна, тъй като мероприятията в рамките на официалното културно сътрудничество се провежАат преАимно в Аелхи и трудно достигат $а$ градовете в различните щати на Индия. Съобразена с цялостната културна политика на България по отношение на Индия и с инАийските условия, работата с тези организации приАобива широк размах и показва големия потенциал при използването на „меки среАства" във външната политика.

35 AMBнР, оп. 35, преп. 1363, ^. 3. / [AMVR, op. 35, Rev. 1363, I. 3.] 

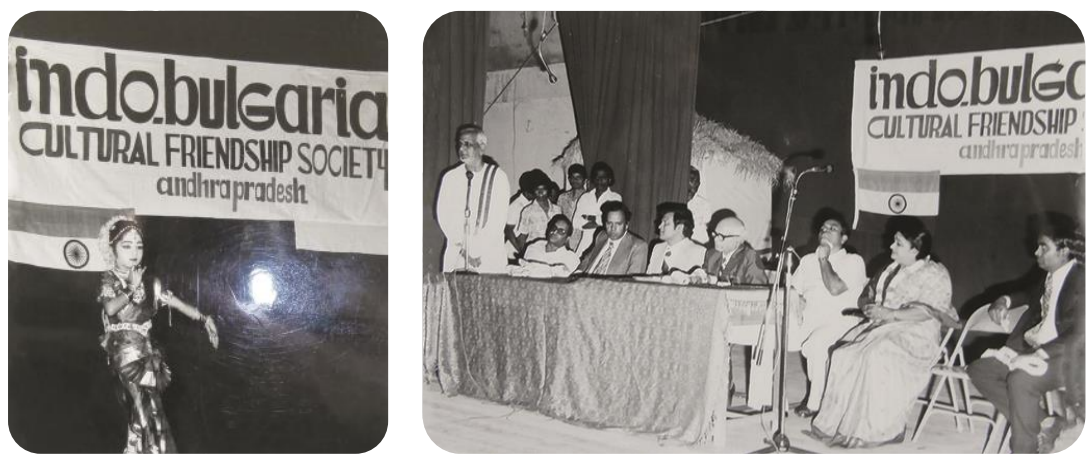

Фигура 1. Източник: ЩАА, ф. 1447, оп. 9, а.е. 620 / [Source: CDA, p.

1447, Op. 9, a.e. 620]

\section{Аитература / References}

Koev, K. (2015). Proektsii na "mekata sila" v mezhdunarodnite otnosheniya. - V: Sbornik nauchni trudove na nauchnata konferentsiya na Rusenski universitet "Angel Kanchev', t. 54, seriya 5.2, sektsiya 'Evropeistika', Ruse. Izdatelski tsentar pri Rusenskiya universitet, 2015, ISBN ISBN 1311-3321, [http://conf.uniruse. $\mathrm{bg} / \mathrm{bg} / \mathrm{docs} / \mathrm{cp} 15 / 5.2 / 5.2-4 . \mathrm{pdf}$, (Last view: 01.04.2019)] // [Коев. К. Проекции на "меката сила" в международните отношения. - В: Сборник научни трудове на научната конорернция на Русенски университет „Ангел Кьнчев", том 54, серия 5.2, секция „Европеистика“, Русе, ИзАателски центьр при Русенскси университет, 2015, ISBN 1311-3321]

Samuilova, S. (2017). Probivi $\vee$ Studenata vojna: obrazovatelni programi na USA vav FRG I NRB. Izd. "Prof. Marin Drinov", Sofiya 2017 // [Самуилова, С. Пробиви в Студената война: образователните обменни програми на САЩ във ФРГ и НРБ.ИзА. "Профр. Марин Аринов", Софиия 2017].

Vasilenko, E. (2016). Kulturnata diplomatsiya kato instrument za 'mekata sila' Geopolitika, 2016/2, [https://geopolitica.eu/spisanie-geopolitika/142-2016/broi-22016/2417-kulturnata-diplomatsiya-kato-instrument-na-amekata-silag, (Last view: 01.04.2019)] // [Васи^енко,Е. Културната Аипломация като инструмент на "меката си^а" Геополитика, 2016/2] 
ПРИ^ОЖЕНИЕ: АМВНР, ОП. 33, а.е. 1258, ^. 15-17

[APPENDIX: AMVR, op. 33, a.e. 1258, I. 15-17]

$\triangle O$

Аругаря Стоян Заимов

Посланик НРБ в ИнАия

Копие:

Ар. М. Скарлатов

Аиректор БКИЦ

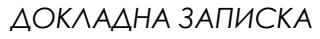

От Ив. Янев, съветник при Посолството

Аругарю Посланик,

По Ваше нарежлане на 8 септември т. г. заминах за гр. Хайдарабал, щата Андра Пралеш, за да взема участие и преАставлявам Посолството в тържественото събрание, уредено от българо-индийското Аружество за приятелство по случай националния празник На НРБ „9-ти септември“.

Веднага ми направи впечатление, че ръководството на нашето Аружество е работило много усърАно и с голяма амбиция за доброто организиране на тържественото събитие. Залата, Андра Сарасвата Паришах хол, еАна от найголемите в града, много Аобре украсена с национални орлагове, лозунги и цветя, бе пълна Ао послеАното място. Гостите бяха наА 500 Ауши - министри, общественици, ръководители на граАа, културни Аейци и членове на Аружеството.

ГАавен гост, както е индийската практика, бе министьр Нарса Реди, министьр на дьржавния бюджет и планирането, а председателстващ общото събрание бе министьрьт на захарната индустрия К. Б. Нарасапа. В президиума бяха още председателят на Аружеството Ралжешвар Рао, зам[естник]Председателят А-р Какала, Ив. Янев, съветник при Посолството на НРБ в Аелхи и няколко преАставители на Аружествата ни от Аруги градове на щата. На събранието говориха всички от президиума. Особено впечатление направи словото на м-р РеАи, който разказа спомени за България от посещението си през 1973 година, когато е бил член на индийската Аелегация на Конгрес на Световния съвет на мира, спирайки се на нашето селско стопанство, което той нарече найразвитото в света. Той апелира към използване на богатия български опит в Индия и за близко сътрудничество с нашата страна. Председателят Р. Рао говори за постиженията в България, за Аейността на Аружеството през послеАните Аве години, за близкото сътруАничество с Посолството и особено наблегна на значението на техния град, на отпуснатите три стипендии за следване в България. 
Тримата м^адежи, накичени с гирлянди из^язоха на сцената и бяха ап^одирани от събранието. Моето слово, което трая около 20 минути, бе топ^о посрещнато от присъстващите.В края на събранието ми бе връчен подарък за Посолството и БКИЦ - художествена картина от най-Аобрата художничка на грала.

СлеА завършване на офрициалната част на събранието бе проведен концерт от индийска и българска музика и танци, изпьлнени от известните артисти Малу Мурти, Валакришна и танцьорката Ажаяшри Раххакришна. СлеА концерта се състоя вечеря, на която присъстваха наА 70 Ауши активисти и ръковоАството на Аружеството. Ръководството на Аружеството подготви и изАале специална брошура от 80 страници специално за нашия празник със статии и материали от всички области на живота в НР България, която бе раздаАена на присъстващите на събранието. Това е елна похвална инициатива на ръководството, много Аобре реализирана, и помагаща за още по-широкото пропагандиране на нашата страна среА индийския нарол.

Накрая може да се каже, че честването на нашия национален празник в Хайлерабал-Секундаребал премина много добре и ще остави следа срел инАийскатаобщественост. Ръководството на Аружеството ни работи много Аобре. Около председателя Ралжешвар Рао е изгрален елин Аобър колектив от миали интелигентни хора, които с Аюбов и ентусиазъм активно работят и популяризират нашата страна, нашите успехи в строителството на социализма. За ма не прекъсва тази активна Аейност на Аружеството, необходимо е БКИЦ реАовно $А$ а подхранва дружеството с необходимите пропагандни материали - фоимми, изложби, книги, пропагандна митература и т.н. Освен това илеята за наемане на помещение за канцеларияи клуб на дружеството трябва $а$ а се подкрепи и се отпуснат при възможност необходимите около 6000 рупии за еАногодишен наем, а необходимият ремонт и мебелировката се извьрши с обществени среАства, които рьководството ще набере от членската маса. Аружеството в Хайлерабал, което ще рьководи Аейността на останалите осем изградени Аружества в щата Андра Пралеш, имайки свой собствен клуб, ще може Ааразърне още по-Аобра

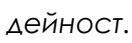

Аелхи, 12 септември 1977 г. Полпис: Ив. Янев 


\section{КУАТУРНО-ИСТОРИЧЕСКО НАСАЕАСТВО: ОПАЗВАНЕ, ПРЕАСТАВЯНЕ, АИГИТААИЗАЦИЯ}

\section{CULTURAL AND HISTORICAL HERITAGE: PRESERVATION, PRESENTATION, DIGITALIZATION}

Научна пореАица: брой 1(6), гоАина V (2019)

Science series: volume 1(6), year V (2019)

\section{ISSN: 2367-8038}

\begin{tabular}{r|l} 
Релактори & Editors \\
Петко Ст. Петков & Petko St. Petkov \\
Галина БогАанова & Galina Bogdanova \\
Институт по математика и & $\begin{array}{l}\text { Institute of Mathematics and } \\
\text { информатика }\end{array}$ \\
Informatics \\
БАН, България & ВAS, Bulgaria
\end{tabular}

Материалите в сборника са обект на авторско право. Разрешава се безвъзмезАното ползване на техни електронни/ хартиени копия само

за лична употреба или с це^ обучение, при писмено указание за мипса на търговски намерения и пьлно цитиране на текста от тази

страница.

За копиране пол Аруга орорма, препубликуване или публикуване на сървъри се изисква писмено разрешение и/и^и заплащане.

() Авторски колектив, 2019

Технически реАактори: Нико^ай Ноев, гА. ас. А-р Калина Сотирова-Вълкова, ас. А-р
This work is subject to copyright. Open and free use of digital/ hard copies of publications is granted only for personal or educational use, while there are written statement for not-commercial intention and full citation of the text of the current page.

For any other reproducing types,

re-publishing, photocopying, recording, orany other storage retrieval system/server is required written permission and/or fee.

(C) Authors` Group, 2019

Technical editors:

Nikolay Noev, Assist. Prof. PhD Kalina Sotirova-Valkova, Assist. Prof. PhD 